КУГАЙ Александр Иванович - доктор философских наук, профессор; профессор кафедры государственного и муниципального управления Северо-Западного института управления - филиала Российской академии народного хозяйства и государственной службы при Президенте РФ (199178, Россия, Санкт-Петербург, Средний пр-кт, B.O., 57/43; kugay3@yandex.ru)

\title{
РУССКАЯ ПРАВОСЛАВНАЯ ЦЕРКОВЬ КАК ИНСТИТУТ ГРАЖДАНСКОГО ОБЩЕСТВА (ФИЛОСОФСКО-МЕТОДОЛОГИЧЕСКИЙ АСПЕКТ)
}

\begin{abstract}
Аннотация. В статье рассматривается церковь как институт гражданского общества в ракурсе гражданства как причастности к политическому сообществу и участия в его жизни. В гражданском обществе, являющемся общественно-политическим разумом нации, церковь как хранитель высших моральных ценностей общества выступает его «совестью». Как организация, оказывающая в своей приходской службе духовные услуги конкретным людям и являющаяся опорой консервативной идеологии, церковь выполняет роль связующего звена между частными и общими интересами, служит институтом гражданского общества, обеспечивающим социальную интеграцию. Фактор влияния института гражданского общества на политический процесс в современном обществе определяется уровнем его участия в трансформации «частного лица» («буржуа», по Г.В.Ф. Гегелю) в «гражданина». В России структурой, конституирующей гражданство и в то же время отвечающей классическим признакам гражданского общества, является Русская православная церковь.

Ключевые слова: власть, государство, религия, гражданское общество, институт гражданского общества, церковь, Русская православная церковь
\end{abstract}

$\mathrm{O}$ чевидно, что институты гражданского общества - не только сообщества граждан, организованные для защиты своих общих интересов за пределами государства. Ресурсы гражданского общества - важнейшее условие общественного развития, фактор защиты цивильных, политических и социальных прав человека. Артикулируя запросы различных групп населения к государственной власти, институты гражданского общества оказывают все более заметное влияние на формирование политической повестки дня. Какое место в современном обществе занимает церковь, каковы возможности ее влияния как института гражданского общества на политические процессы, происходящие в нем?

\section{Становление концепции гражданского общества}

Мы можем проследить происхождение концепции гражданского общества до аристотелевского koinonia politikè (IV в. до н.э.), переводимого на латынь как civitas, civilis communitas и, наконец, как societas civilis. Koinonia politikè - организация древних цивилизаций, или полисов, объединяющая то, что мы сегодня называем общественным и частным, светским и религиозным измерениями. Применительно к городу-государству, такому как Афины, и к республиканскому Риму оно обозначало сложное институциональное устройство со значительным торговым и сельскохозяйственным («частным») сектором, признанием нескольких видов собственности, а также с системой судебных разбирательств и судебной практики, предусматривающей договорную свободу значительной части мужского населения, отвечающего за домашнее хозяйство (oikos). Как граждане эти люди участвовали в публичных дебатах, в избрании широкого круга судей и в распределении бремени не только политических 
решений, но и боевых действий, необходимых для их осуществления. Город смешал временные проблемы и глубокое чувство сакрального и основывался на религиозной связи с божествами, которые защищали город, а также семьи и каждого обитателя этого города.

Во время падения Рима Августин разработал теорию контраста между городом человека - ненадежным механизмом для достижения мира и городом Бога - городом паломников, ожидающих Небесного Дома. Со временем, и наиболее четко начиная с IX в., христианство открыло путь для программы реформ города человека, чтобы сделать его ближе к городу Бога - небесному Иерусалиму, который должен существовать параллельно несовершенному земному Иерусалиму [Taylor 2007]. Например, в северной Италии местные сообщества, основанные на семейных сетях и добровольных ассоциациях, были сознательно организованы и понимались как «города Бога» [Thompson 2005]; а гильдии с их ценностями братства и взаимности являлись основными институтами социальной, религиозной, экономической и политической жизни [Black 1984]. Произошло также возрождение «Политики» Аристотеля, переведенной на латынь в XII в. Идея полиса была подхвачена Фомой Аквинским; он понимал его как communitas politica или civilis communitas, в котором светская власть ограничивалась естественными правами отдельных лиц, семей, ассоциаций и сообществ. Власть правителя была решительно ограничена в моральных вопросах (например, в них отсутствовала учительская власть - potestas docendi) и подчинялась общему благу.

В позднем Средневековье было несколько попыток сформулировать идею упорядоченного политического общества, в котором достигнут баланс между ограничениями на светскую власть и эффективным использованием власти с учетом общего блага, между «либералом» и «гражданином». Бруни (XV в.), будучи активным участником флорентийской политики, механизмы которой, по его мнению, были аналогичны положениям республиканского Рима, ввел понятие societas civilis [Bruni, Zamagni 2004].

Как показывает историография XVIII в., правительства национальных государств вступали в определенный диалог с сегментами своих подданных, постепенно разрешалось религиозное и политическое инакомыслие, увеличивался объем коммерческих сделок. «Свободное правительство, свободная торговля, свободная совесть» объединились. Таким образом, societas civilis (ограниченное правительство, рынки, общественная сфера и добровольные ассоциации) стал не просто концепцией, а историческим горизонтом Европы и Северной Америки [Pocock 1999].

\section{Гражданство и гражданское общество}

Понятие «гражданское общество» непосредственно связано с гражданством как таковым. Несложно заметить их этимологическое родство: гражданин (civitatus) и гражданская община (civitas). Свидетельством того, что civitatus и civitas обладают единым субстанциональным содержанием, историческим и политическим смыслом, является отражение динамики их становления в европейских языках.

Обратимся к понятию «гражданин», к эволюции его становления в английском языке и британской политической культуре. В английском языке понятие citizen (гражданин) возникает только в XVI в. и образовано от city (город). Citizen (гражданин), в отличие от denizen (житель города), не просто проживает городе, но обладает известными правами, предоставленными городом, способностями их реализовать, выполняя свои обязанности в интересах города.

Гражданство в современном употреблении этого термина - продукт Модерна, 
представляющий собой такой принцип отношений между людьми, при котором они рассматриваются как равные друг другу граждане. Основу гражданского общества составляют организации и ассоциации, сформированные в результате свободного волеизъявления граждан, ограниченные законами от прямого вмешательства и произвольной регламентации со стороны государственной власти.

Основу гражданского общества, его институтов образует волеизъявление свободных граждан и добровольно сформировавшиеся ассоциации и организации, огражденные соответствующими законами от прямого вмешательства и произвольной регламентации со стороны государственной власти. Это право на объединение является, пожалуй, самым фундаментальным правом, таким же фундаментальным, как право собственности, и даже более фундаментальным, чем свобода слова. Добровольно сформированные ассоциации представляют собой диффузию власти, соответствующую нашему понятию свободы. Право добровольного объединения означает право проявлять инициативу в создании новых объединений, а также право вступать или не вступать в уже существующие объединения или выходить из них. Право добровольного объединения также является правом добровольного разъединения. Право на добровольное разъединение является центральным для защиты моральной индивидуальности. «Целенаправленное государство посягает на индивидуальное право на свободное объединение двумя способами. Во-первых, оно требует обязательного участия в ассоциациях, поддерживающих цели государства, и подавляет другие, которые могут препятствовать достижению этих целей, какими бы они ни были» [Pérez-Díaz 2014].

Переселенцы, прибывающие в Америку, самоорганизовывались и создавали неправительственные организации до обретения Соединенными Штатами независимости. В трактате «Демократия в Америке» Алексис де Токвиль отмечал: «...если только у нескольких человек в Соединенных Штатах возникает идея, которую они желают продвинуть, они вначале находят друг друга, но как только устанавливают контакты между собой, они объединяются. Начиная с этого момента они уже не одиночки, а образуют заметную силу. В настоящее время в Соединенных Штатах действует около 1,5 млн общественных организаций - независимых добровольных союзов граждан, способствующих утверждению свободы и поддержанию общественного порядка 1 .

В общих чертах можно выделить две проекции понимания гражданства: как подданство и как участие. Как подданство гражданство представляет собой юридические отношения между властью и индивидом, находящимся под ее защитой и юрисдикцией. Соответственно, быть гражданином означает обладать правами, предоставляемыми государством, и использовать их, а также нести установленные обязанности перед ним.

В ракурсе понимания гражданства как участия на первый план выводятся политические отношения. Здесь быть гражданином означает быть причастным к тому или иному политическому сообществу и, соответственно, иметь право участия в его жизни. Отсюда те или иные институты гражданского общества в разной степени участвуют в политической жизни общества: к примеру, спорт во время международных соревнований - фактор национального единства, индикатор социальной политики государства; кинематограф и театр - ресурсы национального самосознания, которые на экране и сцене отражают эпические события национальной истории.

\footnotetext{
${ }^{1}$ Макфол М. Гражданское общество Америки. - Независимая газета. 29.04.2013. Доступ: https://www.ng.ru/ideas/2013-04-29/1_us_society.html (проверено 08.05.2021).
} 


\section{Церковь как институт гражданского общества в ЕС и США}

Церковь как ассоциация, формирующаяся на основе добровольного волеизъявления людей в качестве института гражданского общества, присутствует в политической жизни современного общества в разных ипостасях.

Несмотря на то что в силу мировоззренческой специфики для церкви земная жизнь человека и все, что с ней связано, не является приоритетным, она стремится доступными и приемлемыми средствами и способами защищать права человека, возникшие из христианской догматики, провозгласившей человека «образом и подобием Божьим». Очевидно, что по своей сути естественные права человека, зафиксированные в международном праве, включая экономические, социальные и культурные права, соразмерны христианскому представлению о необходимых условиях человеческой жизни. К тому же признание естественных (Богом данных) прав человека является ферментом, сплачивающим все мировые религии.

В современном демократическом государстве религиозные вероучения выполняют роль регулятора нравственных ценностей в обществе, носителя моральных традиций и устоев. Программы политических партий, законы, музеи, больницы, школы, общественные объединения и даже коммерческие предприятия создаются людьми, у которых есть представление о высшем благе, и они претендуют на наши общие социальные ресурсы, чтобы воплотить продукты своей деятельности в жизнь. И церковь, выступая хранителем Священного предания, институтом его передачи от поколения к поколению, образует духовное основание европейской культуры.

В чем же заключается роль церкви в реализации конституционных прав и свобод человека? Даже отделившись от государства, современная церковь отстаивает в своих отношениях с властью конституционное право верующих исповедовать свои религиозные убеждения и влиять на жизнь общества. Более того, государство гарантирует равенство прав и свобод человека и гражданина независимо от его отношения к религии. Запрещаются любые формы ограничения прав граждан по признаку религиозной принадлежности.

Европейские церковно-государственные отношения на протяжении последнего столетия утверждали главенство политических элит над клерикальными, а общественные институты церкви - школы, духовенство и благотворительность - становились вспомогательными для расширения возможностей государства.

Светские государства предоставляют прямые или косвенные субсидии учреждениям, связанным с признанными конфессиями, например религиозным школам или социальным и медицинским службам. В Германии протестантская и римско-католическая церкви, а также иудаизм (но не ислам) имеют право на федерально собираемые церковные налоги и право управлять субсидируемыми государством религиозными социальными службами и больницами.

Финансирование религиозных учебных заведений, обучение христианского духовенства на богословских факультетах государственных университетов, а также финансируемые государством христианские социальные и медицинские услуги являются примерами проникновения государства в общественные институты национальных церквей и сопутствующей роли церкви в регулировании жизни граждан. Социал-демократические движения XX в. существенно не изменили государственно-церковные отношения. Вместо этого они заключили мир с религией, используя государство для контроля над сектантством.

Сейчас наказания за богохульство существуют в 46 странах, почти треть из них - исламские. Там кощунство, богохульство и оскорбление религиозных чувств 
карается весьма сурово: например, в Саудовской Аравии или Афганистане за это казнят, в Тунисе приговаривают к тюремному заключению. В Судане наказание за богохульство и кощунство - 40 ударов плетью. Законы о богохульстве являются светским выражением запрета в Евангелии от Марка 3: 29: «...а кто богохульствует против Святого Духа, тот никогда не имеет прощения, но виновен в вечном грехе». В юридической практике суды защищают чувства религиозных верующих как группы, а не саму веру. В Уголовном кодексе Австрии, Германии, Греции, Дании, Финляндии действуют запреты на богохульство. В США отсутствует единый федеральный закон о кощунстве, но есть подобные акты в некоторых штатах ${ }^{1}$.

Речь священника - политическая, поскольку всегда связана с текущими социальными процессами, в которых непременно присутствует политика. Уильям X. Ламар IV, пастор митрополичьей Африканской методистской епископальной церкви в Вашингтоне, округ Колумбия, говорил: «Всякий раз, когда мы используем слова, особенно в служении Богу, мы действуем политически. Нет такого понятия, как неполитический язык, особенно когда этот язык дерзает утверждать себя теологически, проповеднически или экклезиологически. Церковь - это молящееся, поющее, проповедующее, свидетельствующее тело. Мы свидетельствуем о непрекращающемся Божьем царстве любви, справедливости, красоты и изобилия во времени и пространстве. Мы оплакиваем сломленность, зло и насилие. Наши молитвы, песни, проповеди и свидетельства - это акты политической речи» 2 .

Религия является источником, а церковь - хранительницей не только личной веры, но и коллективной идентичности. Религиозное большинство склонно рассматривать свою веру как общественную этику, в то время как религиозные меньшинства рассматривают свою веру как этническую принадлежность.

Церковь формулирует теологические ответы на основные вопросы, стоящие перед современным обществом, выделяет неизбежные опасности современности, такие как радикальная секуляризация, любого рода фундаментализм, возможные межэтнические/межрелигиозные конфликты. В католической церкви это делается через папские энциклики. Некоторые энциклики хорошо известны, например Rerum novarum («О положении трудящихся»), Pacem In Terris («Мир на земле»- решение вопросов мира, справедливости, любви и свободы) или более новые, такие как Caritas in Veritate («Любовь в истине», 2009), ставящая истину и любовь в основу социальной доктрины церкви, или Lumen Fidei («Свет веры», 2013), представляющая диалог между верой и разумом и между верой и общим благом.

«Око Господа всевидящее. На этом основано не только европейское право, но и исламский шариат» [Кугай 2020: 146]. «И нет творения, сокрытого от Него, но все обнажено и открыто перед Его глазами: Ему дадим отчет» (Евр. 4:13). Без Абсолюта право не работает. До появления всеобщего избирательного права не существовали списки избирателей, поскольку избирательным правом обладало ограниченное число граждан и предполагалось, что они и без того знают друг друга в лицо. Поэтому, к примеру в США и Англии, избиратели клали руку на Библию, произносили клятву, а проблему достоверности решал судья.

Легитимирующий фактор религии состоит в том, что ее энергия и сила убеждения опираются на собственные основания, воплощенные в понятиях «спасе-

\footnotetext{
${ }^{1}$ Как в Европе судят и судили за оскорбления религии? Доступ: https://team29.org/story/ witchcraft/ (проверено 08.05.2021).

2 William H. Lamar IV, pastor of Metropolitan African Methodist Episcopal Church in Washington. Do politics belong in church? - The Christian Century. 2018. October 10.
} 
ние», «грех» и «покаяние», соответствующих искупительных практиках, независимо от политики. Секуляризация государства и секуляризация общества - это не одно и то же. Поэтому в экстремальных ситуациях экзистенциального выбора «человек оправдывается Верой независимо от дел Закона» [Кугай 2020: 145].

Гражданское общество как социальный строй, покоящийся на личном экономическом интересе, где «каждый для себя - цель, все другие - суть для него ничто» [Гегель 1990: 211], породило фундаментальное противоречие между «буржуа» и «гражданином». Сопутствующим явлением господства капитализма является кризис человека как гражданина, который, как писал Гегель, «работает для всеобщего, имеет последнее своей целью», служит «общему благу» [Гегель 1970: 360]. Особенность психологии буржуа состоит в его неспособности к добровольному коллективному действию, даже когда предполагается, что оно отвечает его частному интересу [Де Токвиль: 312]. В этом смысле буржуа по определению является аполитичным, поскольку лишь коллективное политическое действие обладает способностью трансформировать общественные структуры.

Каким образом и на каком основании современный человек в качестве буржуа будет «трудиться для всеобщего», ведь само определение «буржуа» включает преследование частных, но не всеобщих целей? [Гегель 1990: 362-363].

Причина этого - в не подверженных калькуляции рисках, возникающих в результате коллективных действий, устремленных в неопределенное будущее, в желании возместить затраты, которых невозможно просчитать. Для меркантильного буржуа приносить такие «жертвы», очевидно, нерационально. Поэтому коллективное политическое действие возможно тогда, когда возникнет сила, побуждающая рациональных индивидов действовать самоотверженно в интересах общего блага [Olson 1965: 23].

Силой, отстаивающей «гражданство», способной «не прогибаться» перед более мощной силой «буржуа», является государство со своей разветвленной сетью институтов и те институты гражданского общества, которые оказывают влияние на формирование национального самосознания.

Очевидно, в калейдоскопе институтов гражданского общества церковь как основной хранитель консервативных ценностей является своеобразным мостом между частным и общим, ключевым институтом, обеспечивающим социальную интеграцию. Условием возникновения общества является наличие одинаковых взглядов и мнений о многих вещах. К примеру, в Соединенных Штатах присутствуют различные вероисповедания, но все американцы едины в своем отношении к религии [Де Токвиль: 511-512].

Каналами влияния церкви как хранительницы Предания на политические процессы в Западной и Восточной Европе являются международные христианско-демократические организации, например Европейское христианское политическое движение - европартия, объединяющая национальные партии стран - членов Европейского союза, которые разделяют идеологию христианской демократии. Влияние христианских ценностей и, соответственно, церкви как института гражданского общества осуществляется по каналам многочисленных национальных партий, в названии и программах которых присутствует христианская символика и христианские ценности. В современной Европе таковых более ста.

Несмотря на то что в духовном плане Европа фрагментирована в связи с миграционными потоками, религиозный консерватизм в Европе переживает возрождение. Страх перед вторжением иных религиозных традиций и ценностей, похоже, возрождает общинное представление и политический дискурс о христианской Европе. 


\section{Русская православная церковь как институт гражданского общества в полити- ческом процессе России}

Базовые положения, отражающие официальную позицию Московского патриархата в сфере взаимоотношений с государством и светским обществом по вопросам церковно-государственных отношений и по ряду современных общественно значимых проблем изложены в документах, принятых и освященных Архиерейским собором Русской православной церкви: «Основы социальной концепции Русской Православной Церкви» (2008 г.), «Основы учения Русской Православной Церкви о достоинстве, свободе и правах человека» (июнь 2008 г.), «Отношение Русской Православной Церкви к намеренному публичному богохульству и клевете в адрес Церкви» (2011 г.), «Общественная деятельность православных христиан» (2011г.), «Позиция Церкви в связи с развитием технологий учета и обработки персональных данных» (2013 г.). Документы также устанавливают руководящие принципы, применяемые в данных областях епископатом, клиром и мирянами.

Так, Русская православная церковь «считает очевидным благом свободную и добровольную общественную деятельность, направленную на праведное и достойное устроение жизни, на свидетельство о своей вере делами, на помощь и служение ближнему - во исполнение заповеди Божией: "Возлюби ближнего твоего, как самого себя" (Мф. 22, 39)»1. «Права человека не могут быть выше ценностей духовного мира. Христианин ставит свою веру в Бога и свое общение с Ним выше собственной земной жизни. Поэтому недопустимым и опасным является истолкование прав человека как высшего и универсального основания общественной жизни, которому должны подчиняться религиозные взгляды и практика» 2 . Более того, церковные документы содержат в себе протестный потенциал. В «Основах социальной концепции Русской Православной Церкви» в разделе «Церковь и государство» сказано: «Если власть принуждает православных верующих к отступлению от Христа и Его Церкви, а также к греховным, душевредным деяниям, Церковь должна отказать государству в повиновении» 3 .

Следует признать, что основные механизмы решения актуальных проблем развития России, естественно, и тех, которые находятся в поле зрения институтов гражданского общества, определяются президентом, законодательными и исполнительными органами власти. Соответственно, лоббировать принятие тех или иных решений органами власти способны лишь те институты гражданского общества, которые, во-первых, имеют и официально декларируют свою позицию по ключевым проблемам, связанным с цивильными, политическими и социальными правами граждан, во-вторых, в силу своего особого социального статуса оказывают прямое или косвенное влияние на политический процесс. Таким институтом гражданского общества в современной России является Русская православная церковь.

К тому же после развала социалистического уклада Россия, вступив на путь капиталистического развития, ощутив очевидные преимущества рыночной экономики, решив проблемы дефицита в сфере потребления, столкнулась с известными издержками капитализма, связанными с доминированием частных, буржуазных ценностей над ценностями гражданина, что является непри-

\footnotetext{
1 Общественная деятельность православных христиан. 2011 г. Доступ: http://www. patriarchia.ru/db/text/1400931.html (проверено 08.05.2021).

2 Основы учения Русской Православной Церкви о достоинстве, свободе и правах человека. Доступ: http://www.patriarchia.ru/db/text/428616 (проверено 08.05.2021).

3 Основы социальной концепции Русской Православной Церкви. 2008 г. Доступ: http:// www.patriarchia.ru/db/text/419128 (проверено 08.05.2021).
} 
емлемым для любого национального государства. Основная цель политического гражданства в современном обществе - установление баланса между частнособственнической психологией буржуа и психологией гражданина, живущего интересами общества. В России базовой духовной структурой, формирующей гражданство и в то же время отвечающей классическим признакам гражданского общества, является Русская православная церковь, чья структурно-административная система во многом совпадает с элементами государственной системы: это привязка территориальных границ епархий к границам субъектов РФ, взаимодействие между руководством епархий и губернаторами как отчасти конгруэнтными субъектами организации административного пространства страны.

Став историческим фактором объединения территорий в единое государство, Русская православная церковь в эпоху глобализации выступает символом самобытности страны, критически необходимым для национального самосознания и государственной идентичности.

Таким образом, в ракурсе гражданства как причастности к политическому сообществу и участия в его жизни роль и место церкви как института гражданского общества в пространстве политических отношений определяется следующими факторами.

1. Власть, находящаяся вне общественного контроля, ориентирована на самовоспроизводство, и в этом отношении она асоциальна и аморальна. И только гражданское общество способно предлагать власти определенные смыслы и цели, выходящие за границы ее частных интересов.

2. В гражданском обществе, являющимся общественно-политическим разумом нации, церковь как хранитель высших - религиозных - ценностей общества выступает его «совестью».

3. Церковь есть институт гражданского общества, призванный стоять на страже общественных интересов. В политическом пространстве статус церкви определяется через ограничения, которые налагаются ею посредством воздействия на общественное мнение, на те силы в обществе, которые хотят использовать власть в узкокорпоративных целях, несовместимых с интересами общества.

4. Исходя из того, что власть есть «воля к воле»- определенный способ использования силы, власть церкви - в сохранении и утверждении религиозных ценностей. Она действенна в борьбе - в преодолении ценностей и нравов, противоречащих религиозным нормам.

5. Церковь как институт гражданского общества находится не только в сотрудничестве, но и в оппозиции к действующей власти, всегда нуждающейся в легитимации и вынужденной иметь дело не с легитимированным источником своего могущества - с самодостаточной силой, в качестве которой выступает церковь.

6. Церковь как организация, оказывающая в своей приходской службе духовные услуги конкретным людям и являющаяся опорой консервативной идеологии, выполняет роль связующего звена между частными и общими интересами, служит институтом гражданского общества, обеспечивающим социальную интеграцию.

7. Церковь является хранительницей не только личной веры, но и коллективной идентичности. Религиозное большинство склонно рассматривать свою веру как общественную этику, в то время как религиозные меньшинства рассматривают свою веру как этническую принадлежность.

8. Фактор влияния института гражданского общества на политический процесс в современном обществе определяется уровнем его участия в трансформации «частного лица» («буржуа», по Г.В.Ф. Гегелю) в «гражданина». 
В России структурой, конституирующей гражданство и в то же время отвечающей классическим признакам гражданского общества, является Русская православная церковь.

\section{Список литературы}

Гегель Г.В.Ф. 1970. Йенская реальная философия. - Работы разных лет: в 2 т. М.: Мысль. Т. 1.668 с.

Гегель Г.В.Ф. 1990. Философия права. М.: Мысль. 524 с.

Де Токвиль А. Демократия в Америке. Книга вторая. - Электронная библиотека. Гражданское общество в России. 592 с. Доступ: https://www.civisbook.ru/ files/File/Tokville_Democracy_1.pdf (проверено 08.05.2021).

Кугай А.И. 2020. Религиозные основания власти в современном обществе. Управленческое консультирование. № 5. С. 138-148.

Black A. 1984. Guilds and Civil Society in European Political Thought from the Twelfth Century to the Present. Ithaca, NY: Cornell University Press.

Bruni L., Zamagni S. 2004. Economia civile: Efficienza, equità, felicità pubblica. Milan: Il Mulino.

Olson M. 1965. The Logic of Collective Action. Public Goods and the Theory of Groups. Cambridge, Mass.: Harvard University Press. 216 p.

Pérez-Díaz V. 2014. Civil Society: A Multi-layered Concept. - Current Sociology Review. Vol. 62. Is. 6. P. 812-830.

Pocock J.G.A. 1999. Barbarism and Religion, II: Narratives of Civil Government. Cambridge: Cambridge University Press.

Taylor C.A. 2007. Secular Age. Cambridge, MA; London: Belknap Press of Harvard University Press.

Thompson O.P. 2005. Cities of God: The Religion of the Italian Communes, 11251325. University Park: The Pennsylvania State University Press.

KUGAY Aleksandr Ivanovich, Dr.Sci. (Philos.), Professor of the Chair of State and Municipal Management, NorthWestern Institute of Management - Branch of Russian Presidential Academy of National Economy and Public Administration (RANEPA) (57/43 Sredniy Ave, V.O., St. Petersburg, Russia, 199178; kugay3@yandex.ru)

\section{THE RUSSIAN ORTHODOX CHURCH AS AN INSTITUTION OF CIVIL SOCIETY (PHILOSOPHICAL AND METHODOLOGICAL ASPECT)}

\footnotetext{
Abstract. The article considers church as an institution of civil society from the perspective of citizenship as involvement in the political community and participation in its life. In civil society, which is the socio-political mind of the nation, church as the guardian of the highest moral values of society, acts as its "conscience». As an organization that provides spiritual services to specific people in its parish service and is a pillar of conservative ideology, the church plays the role of a link between private and general interests, serves as an institution of civil society that ensures social integration. The factor of influence of the institution of civil society on the political process in modern society is determined by the level of its participation in the transformation of a "private person» («bourgeois» by G.V.F. Hegel) into a "citizen». In Russia, the structure that constitutes citizenship and at the same time, meets the classical characteristics of civil society is the Russian Orthodox Church.

Keywords: power, state, religion, civil society, institute of civil society, church, Russian Orthodox Church
} 